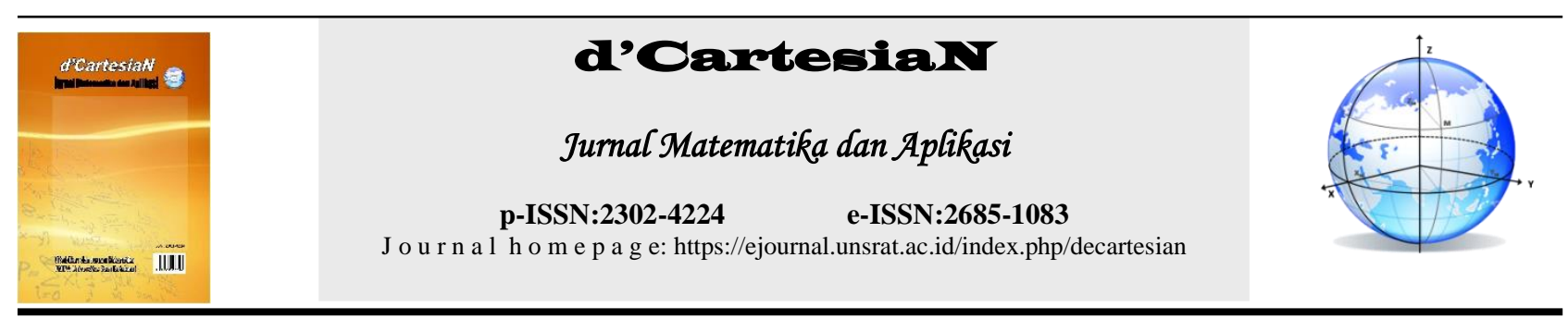

\title{
Analisis Variabel-Variabel Yang Mempengaruhi Pendapatan Keluarga Di Wilayah Tombatu Dua Raya
}

\author{
Ridel Runturambi ${ }^{1}$, Nelson Nainggolan ${ }^{1}$, Djoni Hatidja ${ }^{1^{*}}$ \\ ${ }^{1}$ Mathematics Department-Faculty of Mathematics and Natural Sciences-University of Sam Ratulangi Manado, Indonesia
}

*Corressponding author: dhatidja@unsrat.ac.id

\begin{abstract}
A B S T R A K
Pendapatan merupakan sumber dari pembiayaan yang dilakukan baik oleh seseorang maupun keluarga. Pendapatan adalah penghasilan berupa upah atau gaji, deviden, keuntungan dan merupakan suatu arus uang yang diukur dalam suatu jangka waktu tertentu misalnya seminggu, sebulan, setahun dan jangka waktu yang lebih panjang. Rumah tangga baik ditingkat keluarga maupun pemerintahan pasti membutuhkan biaya untuk memenuhi kebutuhan hidupnya sehari-hari. Biaya tersebut diperoleh dari pendapatan seluruh anggota keluarga tersebut. Pendapatan dalam suatu rumah tangga pasti berbeda-beda. Tujuan penelitian ini adalah untuk Mendeskripsikan pendapatan keluarga wilayah Tombatu Dua Raya dan untuk menentukan variabel-variabel yang mempengaruhi pendapatan keluarga di wilayah Tombatu Dua Raya dengan menggunakan Analisis Regresi. Data yang digunakan dalam penelitian ini adalah data kepala keluarga yang terdapat di Desa Tombatu Dua Raya yang diambil dengan menggunakan kuisioner yang kemudian diolah dengan menggunakan aplikasi pengolahan data statistika. Digunakan total 91 data kepala keluarga yang diolah dengan menggunakan metode analisis regresi didapatkan pendapatan keluarga diwilayah Tombatu Dua Raya dengan Total sampel 91 sampel, di peroleh rata-rata Rp.2.835.165, standard deviasi Rp.1.673.411, dengan pendapatan minimum berjumlah Rp.1.00o.00o dan pendapatan maximum berjumlah Rp.10.000.00o dengan variabel-variabel yang mempengaruhi adalah Luas Lahan, Kepala keluarga yang mempunyai pekerjaan swasta dan PNS memiliki pendapatan berbeda dengan kepala keluarga yang memiliki pekerjaan petani, Keluarga yang memiliki Daya Listrik 9oo Watt memiliki pendapatan berbeda dengan keluarga yang memiliki daya listrik 450 Watt.
\end{abstract}

\section{INFO ARTIKEL}

Diterima: 21 Januari 2020

Diterima setelah revisi: 23 Januari 2020

Tersedia online : 25 Januari 2020

Kata Kunci:

Analisis Regresi

Pendapatan

Tombatu Dua Raya

\begin{abstract}
A B S T RACT
Income is a source of financing carried out both by a person and family. Income is an earning in the form of wages or salaries, dividends, profits and is a cash flow that is measured in a certain period of time for example a week, a month, a year or a longer period of time. Households, both at the family and government level, definitely need money to meet their daily needs. The fee is obtained from the income of all family members. Income in a household must vary. The purpose of this study is to describe the family income of the Tombatu Dua Raya region and to determine the variables that affect family income in the Tombatu Dua Raya region by using Regression Analysis. The data used in this study is the data of the head of the family in the village of Tombatu Dua Raya which was taken using a questionnaire which was then processed using a statistical data processing application. A total of 91 head of household data processed using the regression analysis method obtained family income in the Tombatu Dua Raya region with a total sample of 91 samples, an average of Rp.2.835.165, a standard deviation of Rp.1.673.411, with the minimum income of Rp. 1.000.000 and a maximum income of Rp.10.000.000, The variables that influence are land area, family heads who have private work and civil servants have different income from heads of families who have farmer jobs, families with 900 watts of electricity have income is different from a family that has 450 Watt of electricity.
\end{abstract}

\section{ARTICLE INFO}

Accepted: 21 January 2020

Accepted after revision: 23 january 2020

Available online: 25 January 2020

Keywords:

earnings

Regresion Analysis

Tombatu Dua Raya

\section{PENDAHULUAN}

Pendapatan merupakan sumber dari pembiayaan yang dilakukan baik oleh seseorang maupun keluarga. Menurut [1] pendapatan adalah penghasilan berupa upah atau gaji, deviden, keuntungan dan merupakan suatu arus uang yang diukur dalam suatu jangka waktu tertentu misalnya seminggu, sebulan, setahun atau jangka waktu yang lebih panjang. Selanjutnya [2] menambahkan, pendapatan adalah segala macam uang yang diterima secara tetap oleh perorangan, keluarga atau organisasi misalnya upah, gaji, laba dan lain-lain. Pendapatan itu sendiri digunakan untuk memenuhi kebutuhan keluarga, antara lain untuk pakaian, makan, rumah atau tempat tinggal dan pendidikan.

Sebagian orang tidak bisa memenuhi semua kebutuhan keluarga, hal ini dikarenakan keterbatasan pendapatan. Padahal menurut [3] 70,6\% dari pendapatan rumah tangga miskin digunakan untuk konsumsi makanan. Kondisi ini umumnya terjadi di 


\section{ANALISIS VARIABEL-VARIABEL YANG MEMPENGARUHI PENDAPATAN KELUARGA DI WILAYAH TOMBATU \\ DUA RAYA}

d'Cartesian Jurnal Matematika dan Aplikasi, Vol. 9, No. 1 (Maret, 2020): 62-71

pedesaan. Lain halnya dengan pola konsumsi keluarga mampu. karena kebutuhan pokoknya yaitu sandang, pangan dan papan sudah terpenuhi, mereka mampu memenuhi kebutuhan pendidikan.

Penelitian terkait faktor-faktor yang mempengaruhi pendapatan rumah tangga di tingkat pedesaan sangat penting dilakukan untuk menunjang program pemerintah dalam menuntaskan kemiskinan. Dengan menggunakan analisis regresi. Selanjutnya [4] meneliti seberapa besar pengaruh variabel yang telah dipilih yaitu jumlah anggota keluarga (X1), luas lahan (X2), jumlah pohon pala (X3), jumlah produksi biji pala (X4), biaya tenaga kerja (X5) dan biaya produksi (X6) terhadap pendapatan petani pala di Desa Sensong dengan menggunakan analisis regresi berganda. Variabel yang memiliki pengaruh terhadap pendapatan petani pala pada jumlah produksi biji pala $\left(\mathrm{X}_{4}\right)$ dan biaya produksi (X6). Selanjutnya [5] melakukan penelitian penentuan model regresi terbaik dengan menggunakan metode stepwise dengan hasil mendapatkan variabel- variabel yang mempengaruhi impor beras di Sulawesi Utara dan mendapat model regresi terbaik dari impor beras di Sulawesi Utara.

Tombatu Dua Raya terletak di Kecamatan Tombatu Utara, Kabupaten Minahasa Tenggara, Provinsi Sulawesi Utara. Dalam rangka untuk peningkatan pembangunan dan perekonomian daerah maka Pemerintah Daerah Tombatu Dua Raya telah melakukan pemekaran wilayah menjadi empat desa yaitu; Desa Tombatu Dua Induk, Tombatu Dua Barat, Tombatu Dua Tengah dan Tombatu Dua Utara. Penelitian ini dimaksudkan untuk mengetahui variabelvariabel yang mempengaruhi tingkat pendapatan keluarga dari keempat desa tersebut setelah pemekaran daerah dengan menggunakan Analisis Regresi.

\section{Analisis Regresi}

Analisis Regresi merupakan salah satu teknik analisis data dalam statistika yang seringkali digunakan untuk mengkaji hubungan antara beberapa variabel dan meramal suatu variabel [6]. Istilah "regresi" pertama kali dikemukakan oleh Sir Francis Galton (1822-1911), seorang antropolog dan ahli meteorologi terkenal dari Inggris. Dalam makalahnya yang berjudul "Regression towards mediocrity in hereditary stature", yang dimuat dalam Journal of the Anthropological Institute, volume 15, hal. 246-263, tahun 1885. Galton menjelaskan bahwa biji keturunan tidak cenderung menyerupai biji induknya dalam hal besarnya, namun lebih medioker (lebih mendekati rata-rata) lebih kecil daripada induknya kalau induknya besar dan lebih besar daripada induknya kalau induknya sangat kecil [7].

Dalam mengkaji hubungan antara beberapa variabel menggunakan analisis regresi, terlebih dahulu peneliti menentukan satu variabel yang disebut dengan variabel tidak bebas dan satu atau lebih variabel bebas. Jika ingin dikaji hubungan atau pengaruh satu variabel bebas terhadap variabel tidak bebas, maka model regresi yang digunakan adalah model regresi linier sederhana. Jika variabel bebasnya lebih dari satu maka digunakan model regresi berganda. Untuk mendapatkan model regresi berganda digunakan estimasi terhadap parameter-parameternya, misalnya metode kuadrat terkeceil (least square method) dan metode kemungkinan maksimum (maximum likelihood estimation)[6]. Pada penelitian ini dikaji analisis regresi linier berganda atau sering juga disebut dengan regresi klasik dengan menggunakan metode kuadrat terkecil [8].

\section{Regresi Linier Berganda}

Bentuk umum model regresi linier berganda dengan $\mathrm{p}$ variabel bebas adalah seperti pada persamaan (1) berikut.

$Y_{i}=\beta_{0}+\beta_{1} X_{i 1}+\beta_{2} X_{i 2}+\cdots+\beta_{p} X_{i, p}+\varepsilon_{i}$

Dimana:

$Y_{i}$ adalah variabel tidak bebas untuk pengamatan ke- $i$, untuk $i=1,2, \ldots, \mathrm{n}$.

$\beta_{0}, \beta_{1}, \beta_{2}, \ldots, \beta_{p}$, adalah parameter.

$X_{i 1}, X_{i 2}, \ldots, X_{i, p}$ adalah variabel bebas.

$\varepsilon_{i}$ adalah galat (error) untuk pengamatan ke-i yang diasumsikan berdistribusi normal yang saling bebas dan identik dengan rata-rata o (nol) dan variansi $\sigma^{2}$.

Dalam notasi matriks persamaan (1) dapat ditulis menjadi persamaan (2) berikut.

$$
Y=X \beta+\varepsilon
$$

Dimana:

$$
\begin{array}{r}
Y=\left(\begin{array}{c}
Y_{1} \\
Y_{2} \\
\vdots \\
Y_{n}
\end{array}\right),=\left(\begin{array}{ccccc}
1 & X_{11} & X_{12} & \ldots & X_{1, p} \\
1 & X_{21} & X_{22} & \ldots & X_{2, P} \\
\vdots & \vdots & \vdots & \ddots & \vdots \\
1 & X_{n 1} & X_{n 2} & \ldots & X_{n, p}
\end{array}\right), \\
=\left(\begin{array}{c}
\beta_{0} \\
\beta_{1} \\
\vdots \\
\beta_{p}
\end{array}\right) \text { dan } \varepsilon=\left(\begin{array}{c}
\varepsilon_{0} \\
\varepsilon_{1} \\
\vdots \\
\varepsilon_{n}
\end{array}\right)
\end{array}
$$

$Y$ adalah vektor variabel tidak bebas berukuran $n \times 1$

$X$ adalah matriks variabel bebas berukuran $n \times(p+1)$

$\beta$ adalah vektor parameter berukuran $(p+1) \times 1$

$\varepsilon$ adalah vektor error berukuran $n \times 1$

\section{Uji Statistik}

\section{Uji Koefisien Determinasi $\mathbf{R}^{2}$}

Untuk mengetahui metode estimasi yang memberikan hasil yang lebih baik, maka kriteria yang digunakan adalah dengan membandingkan nilai $\mathrm{R}-$ Square $\left(R^{2}\right)$ yang menunjukan seberapa besar proporsi variasi variabel tidak bebas yang dijelaskan oleh variabel bebas. Nilai $\left(R^{2}\right)$ yang kecil berarti kemampuan variable;-variabel bebas dalam menjelaskan variasi variabel tidak bebas sangat terbatas. Nilai yang mendekati satu berarti variabelvariabel bebas memberikan hampir semua informasi yang dibutuhkan untuk memprediksi variasi variabel tidak bebas. Apabila nilai koefisien determinasi semakin besar, maka semakin besar kemampuan semua variabel bebas dalam menjelaskan varians dari variabel tidak bebasnya [9].

$\mathrm{R}=\frac{\text { Jumlah kuadrat regresi }}{\text { jumlah kuadrat total }}$

\section{Uji F Bagi Hubungan Regresi}

Untuk menguji apakah ada hubungan regresi antara peubah tak bebas $\mathrm{Y}$ dengan peubah peubah bebas $X_{1}, \cdots, X_{p}$, dengan kata lain untuk memilih diantara alternatif- alternatif :

$H_{0}: \beta_{1}=\beta_{2}=\cdots \beta_{p}=0$

$\mathrm{H}_{1}$ : tidak semua $\beta_{\mathrm{k}}$ sama dengan nol

Kita menggunakan statistik uji :

$F^{*}=\frac{K T R}{K T G}$

Kaidah keputusan dengan galat jenis 1 dikendalikan sebesar $\alpha$ adalah :

Jika $\mathrm{F}^{*} \leq \mathrm{F}(1-\alpha ; \mathrm{p}, \mathrm{n}-\mathrm{p})$, terima $\mathrm{H}_{0}$ Jika $F^{*}>F(1-\alpha ; p, n-p)$, terima $\mathrm{H}_{1}$ 
Adanya hubungan regresi itu saja tidak menjamin bahwa persamaan regresi itu bisa digunakan sebagai alat peramal yang bermanfaa.

\section{Uji Koefisien Regresi Parsial (Uji T)}

Tujuan dari uji parsial adalah untuk mengetahui seberapa jauh pengaruh dari variabel independent (X) terhadap variabel dependent (Y). Pengujian hipotesis akan dilakukan dengan menggunakan tingkat signifikan sebesar 0,05 ( $\alpha=5 \%)$ atau tingkat keyakinan sebesar 0,95 [10]. Hipotesis dirumuskan sebagai berikut :

$H_{0}: \beta_{k}=0$

1: $\beta_{k} \neq 0$

Kita dapat menggunakan statistik uji :

$t^{*}=\frac{b_{k}}{s\left(b_{k}\right)}$

$\mathrm{b}_{\mathrm{k}}=$ koefisien regresi variabel ke- $\mathrm{k}$

$s\left(b_{k}\right)=$ standard deviasi koefisien regresi ke-k

Kaidah keputusan :

$$
\text { jika }\left|t^{*}\right| \leq t\left(\frac{\alpha}{2} ; n-p-1\right), \text { terima } H_{0}
$$

Jika selainnya, terima $H_{a}$

\section{Uji Asumsi Klasik}

Sebelum dilakukan pengujian analisis regresi linier berganda terhadap hipotesis penelitian, maka terlebih dahulu dilakukan suatu pengujian asumsi klasik atas data yang akan diolah sebagai berikut:

\section{Uji Normalitas}

Uji normalitas bertujuan untuk menguji apakah dalam model regresi, variabel pengganggu atau residual memiliki distribusi normal. Seperti diketahui bahwa uji t dan $\mathrm{F}$ mengasumsikan bahwa nilai residual mengikuti distribusi normal. Kalau asumsi ini dilanggar maka uji statitstik menjadi tidak valid untuk jumlah sampel kecil. Ada dua cara untuk mendeteksi apakah residual berdistribusi normal atau tidak yaitu dengan analisis grafik dan uji statistik. Untuk menguji apakah data berdistribusi normal atau tidak dilakukan uji statistik Ryan-Joiner (Shimilar to Shapiro-Wilk). Residual berdistribusi normal jika memiliki nilai signifikan > 0,05 [11].

\section{Uji Heteroskedastisitas}

Uji heteroskedastisitas bertujuan menguji apakah dalam model regresi terjadi ketidaksamaan variance dari residual satu pengamatan ke pengamatan yang lain. Ada beberapa cara yang dapat dilakukan untuk melakukan uji heteroskedastisitas, yaitu uji Park, uji Glejser dan uji White. Pengujian pada penelitian ini menggunakan Grafik Plot antara lain nilai prediksi variabel dependen yaitu standart predicted value (ZPRED) dengan standart residu (SRESID). Tidak terjadi heteroskedastisitas apabila tidak ada pola yang jelas, serta titik- titik menyebar di atas dan di bawah angka o pada sumbu Y.

\section{METODOLOGI PENELITIAN}

\section{Waktu dan Tempat Penelitian}

Penelitian dilaksanakan sekitar 4 bulan. Sejak Juni 2019 sampai Oktober 2019. Tempat penelitian di wilayah Tombatu Dua Raya dan analisis data dilakukan di Laboratorium Statistika Jurusan Matematika, Fakultas Matematika dan Ilmu Pengetahuan Alam Universitas Sam Ratulangi Manado.

\section{Populasi dan Sampel Populasi}

Populasi dalam penelitian ini adalah semua kepala keluarga yang berdomisili tetap di wilayah Tombatu Dua Raya berjumlah 957.

\section{Sampel}

Sampel yang digunakan dalam penelitian ini adalah data kepala keluarga yang terambil di wilayah Tombatu Dua Raya, dengan jumlah sampel yang didapatkan $n=90.53=91$ sampel. Pengambilan sampel dilakukan dengan menggunakan penarikan contoh acak sederhana (simple random sampling). Besarnya sampel ditentukan dengan rumus sebagai berikut:

$$
n=\frac{N}{N \cdot d^{2}+1}=\frac{957}{957 \cdot(0,01)+1}=90,53=91
$$

Dimana:

$n=$ jumlah sampel

$N=$ jumlah populasi

$d^{2}=$ presisi yang ditetapkan (10\%)[12] Pengambilan jumlah sampel dari keempat desa di Wilayah Tombatu Dua Raya menggunakan rumus alokasi sebanding:

$$
n i=\frac{N i}{N} n
$$

\begin{tabular}{|c|c|c|c|c|c|}
\hline \multicolumn{6}{|c|}{ Raya } \\
\hline & $\begin{array}{l}\text { Tombatu } \\
\text { Dua Induk }\end{array}$ & $\begin{array}{c}\text { Tombat } \\
\text { u Dua } \\
\text { Utara }\end{array}$ & $\begin{array}{c}\text { Tombatu } \\
\text { Dua Barat }\end{array}$ & $\begin{array}{c}\text { Tombatu } \\
\text { Dua } \\
\text { Tengah }\end{array}$ & Jumlah \\
\hline $\mathrm{Ni}$ & N1 & $\mathrm{N} 2$ & $\mathrm{~N}_{3}$ & $\mathrm{~N}_{4}$ & $\begin{array}{c}\mathrm{N}_{1}+\mathrm{N}_{2}+ \\
\mathrm{N}_{3}+\mathrm{N}_{4}\end{array}$ \\
\hline ni & $\mathrm{n} 1$ & $\mathrm{n} 2$ & $\mathrm{n} 3$ & $\mathrm{n} 4$ & $\begin{array}{c}\mathrm{n} 1+\mathrm{n} 2+\mathrm{n} \\
3+\mathrm{n} 4\end{array}$ \\
\hline
\end{tabular}

Tabel 1. Notasi Jumlah Sampel di Wilayah Tombatu Dua

$$
\begin{aligned}
& n 1=\frac{N 1}{N} n=\frac{293}{957} 91=27,86=28 \\
& n 2=\frac{N 2}{N} n=\frac{161}{957} 91=15,30=15 \\
& n 3=\frac{N 3}{N} n=\frac{269}{957} 91=25,57=26 \\
& n 4=\frac{N 4}{N} n=\frac{234}{957} 91=22,25=22
\end{aligned}
$$

Tabel 2. Jumlah Sampel di Wilayah Tombatu Dua Raya

\begin{tabular}{|c|c|c|c|c|c|}
\hline & $\begin{array}{c}\text { Tombatu } \\
\text { Dua Induk }\end{array}$ & $\begin{array}{c}\text { Tombatu } \\
\text { Dua Utara }\end{array}$ & $\begin{array}{c}\text { Tombatu } \\
\text { Dua } \\
\text { Barat }\end{array}$ & $\begin{array}{c}\text { Tombatu } \\
\text { Dua } \\
\text { Tengah }\end{array}$ & Jumlah \\
\hline $\mathrm{Ni}$ & 293 & 161 & 269 & 234 & 957 \\
\hline $\mathrm{Ni}$ & 28 & 15 & 26 & 22 & 91 \\
\hline
\end{tabular}

\section{Metode Penelitian}

Penelitian ini menggunakan data primer yang diperoleh dari masyarakat wilayah Tombatu Dua Raya.

Analisis data dilakukan dengan program Minitab Statistic version 18. Berikut ini adalah persamaan regresi berganda berdasarkan kasus yang ada.

$Y=\beta_{0}+\beta_{1} X_{1}+\beta_{2} X_{2}+\beta_{3} X_{3}+\beta_{4} X_{4}+\beta_{5} X_{5}+\beta_{6} X_{6}+\beta_{7} X_{7}+\varepsilon$ Dimana:

$\mathrm{Y}=$ Pendapatan Keluarga

$\mathrm{B}_{\mathrm{o}}, \beta_{1, \ldots, \beta_{7}}=$ Parameter koefisien regresi

$\mathrm{X}_{1}=$ Tingkat Pendidikan Terakhir 
$\mathrm{X}_{2}=$ Pekerjaan

$\mathrm{X}_{3}=$ Luas Lahan kering $(\mathrm{Ha})$

$\mathrm{X}_{4}=$ Luas Sawah (Ha)

$\mathrm{X}_{5}=$ Luas Rumah $\left(\mathrm{m}^{2}\right)$

$\mathrm{X}_{6}=$ Jenis Rumah

$\mathrm{X}_{7}=$ Daya Listrik (Watt)

$\varepsilon=$ Galat

Keterangan:

Variabel $\mathrm{X}_{3}, \mathrm{X}_{4}$, dan $\mathrm{X}_{5}$ adalah variabel yang berskala rasio.

Variabel $\mathrm{X}_{1}, \mathrm{X}_{6}$, dan $\mathrm{X}_{7}$ adalah variabel yang berskala ordinal.

Variabel $\mathrm{X}_{2}$ adalah variabel yang berskala nominal.

$\mathrm{X} 1=$ Tingkat Pendidikan terdiri dari: $1=\mathrm{SD} ; 2=\mathrm{SMP} ; 3=\mathrm{SMA} ; 4=\mathrm{D} 1 ; 5=\mathrm{D} 2 ; 6=$

D3; $7=\mathrm{S} 1 ; 8=\mathrm{S} 2$.

$\mathrm{X} 2=$ Pekerjaan terdiri dari:

1= Petani; $2=$ Swasta; $3=$ PNS.

X6= Jenis Rumah terdiri dari:

1= Papan; 2= Semi Permanen; 3= Permanen.

$\mathrm{X}_{7}=$ Daya Listrik terdiri dari:

$1=450$ Watt; $2=900$ Watt; $3=1300$ Watt; 4=2200Watt.

Analisis regresi untuk variabel berskala ordinal dan nominal menggunakan variabel dummy:

Tabel 3. Variabel Dummy dari Pendidikan $\left(\mathrm{X}_{1}\right)$

\begin{tabular}{|c|c|c|c|c|c|c|c|c|}
\hline $\mathrm{X} 1$ & $\begin{array}{r}\mathrm{X} 1 \\
-1\end{array}$ & $\begin{array}{c}\mathrm{X} 1 \\
2\end{array}$ & $\begin{array}{c}\mathrm{X} 1 \\
3\end{array}$ & $\begin{array}{r}\mathrm{X} 1 \\
4\end{array}$ & $\begin{array}{c}\mathrm{X} 1 \\
5\end{array}$ & $\begin{array}{r}\mathrm{X} 1 \\
6\end{array}$ & $\begin{array}{c}\mathrm{X} 1 \\
7\end{array}$ & $\begin{array}{c}\mathrm{X} 1 \\
8\end{array}$ \\
\hline SD & 1 & o & O & O & o & o & o & 0 \\
\hline SMP & o & 1 & o & o & o & o & o & 0 \\
\hline SMA & 0 & o & 1 & O & 0 & o & O & 0 \\
\hline D1 & o & o & o & 1 & o & o & O & 0 \\
\hline D2 & o & o & $\mathrm{O}$ & O & 1 & o & O & 0 \\
\hline D3 & 0 & o & O & O & o & 1 & O & 0 \\
\hline S1 & 0 & o & o & o & o & o & 1 & 0 \\
\hline S2 & 0 & 0 & 0 & 0 & o & o & 0 & 1 \\
\hline
\end{tabular}

Tabel 4. Variabel Dummy dari Pekerjaan $\left(\mathrm{X}_{2}\right)$

\begin{tabular}{|l|c|c|c|}
\hline X2 & X2_1 & X2_2 & X2_3 \\
\hline Petani & 1 & 0 & 0 \\
\hline Swasta & 0 & 1 & 0 \\
\hline PNS & 0 & 0 & 1 \\
\hline
\end{tabular}

Tabel 5. Variabel Dummy dari Jenis Rumah $\left(\mathrm{X}_{6}\right)$

\begin{tabular}{|l|c|c|c|}
\hline X6 & X6_1 & X6_2 & X6_3 \\
\hline Papan & 1 & 0 & 0 \\
\hline Semi Permanen & 0 & 1 & 0 \\
\hline Permanen & 0 & 0 & 1 \\
\hline
\end{tabular}

Tabel 6. Variabel Dummy dari Daya Listrik $\left(\mathrm{X}_{7}\right)$

\begin{tabular}{|l|c|c|c|c|}
\hline $\mathrm{X}_{7}$ & $\mathrm{X}_{7 \_1}$ & $\mathrm{X}_{7 \_2}$ & $\mathrm{X}_{7 \_3}$ & $\mathrm{X}_{7 \_4}$ \\
\hline 450 & 1 & 0 & 0 & 0 \\
\hline 900 & 0 & 1 & 0 & 0 \\
\hline 1300 & 0 & 0 & 1 & 0 \\
\hline 2200 & 0 & 0 & 0 & 1 \\
\hline
\end{tabular}

Model regresi dengan menggunakan variabel dummy yaitu:

$\mathrm{Y}_{\mathrm{i}}=\beta_{\mathrm{o}}+\beta_{11} \mathrm{X}_{1 \_1}+\beta_{12} \mathrm{X}_{1 \_2}+\beta_{13} \mathrm{X}_{1 \_3}+\beta_{14} \mathrm{X}_{1 \_4}+\beta_{15} \mathrm{X}_{1 \_5}+$ $\beta_{16} \mathrm{X}_{1 \_6}+\beta_{17} \mathrm{X}_{1 \_7}+\beta_{18} \mathrm{X}_{1 \_8}+\beta_{21} \mathrm{X}_{2 \_1}+\beta_{22} \mathrm{X}_{2 \_2}+\beta_{23} \mathrm{X}_{2 \_3}$ $+\beta_{3} \mathrm{X}_{3 \mathrm{i}}+\beta_{4} \mathrm{X}_{4 \mathrm{i}}+\beta_{5} \mathrm{X}_{5 \mathrm{i}}+\beta_{61} \mathrm{X}_{6 \_1}+\beta_{62} \mathrm{X}_{6 \_2}+\beta_{63} \mathrm{X}_{6 \_3}+$ $\beta_{71} X_{7 \_1}+\beta_{72} X_{7 \_2}+\beta_{73} X_{7 \_3}+\varepsilon_{i}$

Adapun langkah-langkah dalam melakukan analisis yaitu:

1. Melakukan pengambilan data primer yang diperoleh dari masyarakat wilayah Tombatu Dua Raya,

2. Mendeskripsikan Variabel-variabel $\mathrm{Y}, \mathrm{X}_{1}, \mathrm{X}_{2}$, $\mathrm{X}_{3}, \mathrm{X}_{4}, \mathrm{X}_{5}, \mathrm{X}_{6}, \mathrm{X}_{7}$,

3. Melakukan uji asumsi klasik agar dapat diketahui apakah model regresi yang baik atau tidak yaitu: uji normalitas residual dan uji heteroskedastisitas (Gujarati, 2012), dan

4. Selanjutnya dilakukan analisis regresi.

\section{HASIL DAN PEMBAHASAN}

\section{Deskripsi Data}

Berdasarkan hasil penelitian yang telah dilakukan, maka hasil disajikan dalam bentuk penyajian data yang sesuai dengan hasil data yang diperoleh dari kuisioner. Penelitian ini menggunakan sampel berupa data-data tentang pendapatan keluarga, tingkat pendidikan terakhir, pekerjaan, luas lahan kering, luas sawah, luas rumah, jenis rumah, daya listrik, dan memiliki jamban. Yang disajikan pada tabel berikut:

1. Pendapatan Keluarga $(Y)$

Dari hasil kuisioner pendapatan keluarga yang diberikan kepada 91 sampel kepala keluarga di wilayah Tombatu Dua Raya, diperoleh data seperti yang dapat dilihat pada Tabel 7 .

Tabel 7. Deskripsi Pendapatan Keluarga di Wilayah Tombatu Dua Raya

\begin{tabular}{|c|c|c|c|c|c|}
\hline Variabel & $\begin{array}{l}\text { Total } \\
\text { Sampel }\end{array}$ & $\begin{array}{l}\text { Rata- } \\
\text { rata }\end{array}$ & $\begin{array}{l}\text { St- } \\
\text { Dev }\end{array}$ & $\begin{array}{l}\text { Mini- } \\
\text { mum }\end{array}$ & $\begin{array}{l}\text { Maxi- } \\
\text { mum }\end{array}$ \\
\hline $\begin{array}{l}\text { Tombatu Dua } \\
\text { Induk }\end{array}$ & 28 & $\begin{array}{l}31071 \\
43\end{array}$ & $\begin{array}{l}1992 \\
380\end{array}$ & $\begin{array}{l}10000 \\
00\end{array}$ & $\begin{array}{l}10000 \\
000\end{array}$ \\
\hline $\begin{array}{l}\text { Tombatu Dua } \\
\text { Utara }\end{array}$ & 15 & $\begin{array}{l}21333 \\
33\end{array}$ & $\begin{array}{l}1008 \\
299\end{array}$ & $\begin{array}{l}10000 \\
00\end{array}$ & $\begin{array}{l}50000 \\
00\end{array}$ \\
\hline $\begin{array}{l}\text { Tombatu Dua } \\
\text { Barat }\end{array}$ & 26 & $\begin{array}{l}2730 \\
769\end{array}$ & $\begin{array}{l}1790 \\
144\end{array}$ & $\begin{array}{l}10000 \\
00\end{array}$ & $\begin{array}{l}10000 \\
000\end{array}$ \\
\hline $\begin{array}{l}\text { Tombatu Dua } \\
\text { Tengah }\end{array}$ & 22 & $\begin{array}{c}3090 \\
909\end{array}$ & $\begin{array}{l}1368 \\
318\end{array}$ & $\begin{array}{l}10000 \\
00\end{array}$ & $\begin{array}{l}50000 \\
00\end{array}$ \\
\hline Total & 91 & $\begin{array}{l}28351 \\
65\end{array}$ & $\begin{array}{l}1673 \\
411\end{array}$ & $\begin{array}{l}10000 \\
00\end{array}$ & $\begin{array}{l}10000 \\
000\end{array}$ \\
\hline
\end{tabular}


Nilai pada variabel seperti yang dapat dilihat pada Tabel 7 merupakan hasil kuisioner pendapatan keluarga. Desa Tombatu Dua Induk dengan jumlah sampel 28 kepala keluarga memiliki rata-rata pendapatan Rp.3.107.143, standard deviasi berjumlah Rp.1.992.380, dengan pendapatan minimum Rp.1.000.000 dan pendapatan maximum Rp.10.000.000. Desa Tombatu Dua Utara dengan jumlah sampel 15 kepala keluarga memiliki rata-rata pendapatan Rp. 2.133.333, standard deviasi berjumlah Rp.1.008.299, dengan pendapatan minimum berjumlah Rp.1.000.00o dan pendapatan maximum berjumlah Rp.5.000.000. Desa Tombatu Dua Barat dengan jumlah 26 sampel memiliki rata-rata pendapatan Rp. 2.730.769, standard deivasi berjumlah Rp.1.790.144,dengan pendapatan minimum berjumlah Rp.1.000.00o dan pendapatan maximum berjumlah Rp.10.000.000. Desa Tombatu Dua Tengah dengan jumlah 22 sampel memiliki rata-rata pendapatan Rp.3.090.909, standard deviasi Rp.1.368.318, dengan pendapatan minimum berjumlah Rp.1.000.00o dan pendapatan maximum berjumlah Rp.5.ooo.ooo. Maka didapatkan untuk pendapatan keuarga diwilayah Tombatu Dua Raya dengan Total sampel 91 sampel, di peroleh rata-rata Rp.2.835.165, standard deviasi Rp.1.673.411, dengan pendapatan minimum berjumlah Rp.1.000.000 dan pendapatan maximum berjumlah Rp.10.000.000.

\section{Tingkat Pendidikan Terakhir $\left(\mathrm{X}_{1}\right)$}

Dari hasil kuisioner tingkat pendidikan terakhir yang diberikan kepada 91 sampel kepala keluarga di wilayah Tombatu Dua Raya diperoleh data yang dapat dilihat pada Tabel 8.

Tabel 8. Deskripsi Tingkat Pendidikan Terakhir di Wilayah Tombatu Dua Raya

\begin{tabular}{|c|c|c|c|c|c|c|c|c|c|}
\hline \multirow[b]{2}{*}{ Desa } & \multicolumn{8}{|c|}{ Pendidikan } & \multirow[b]{2}{*}{$\begin{array}{l}\text { Jum- } \\
\text { lah }\end{array}$} \\
\hline & $\begin{array}{l}\mathrm{S} \\
\mathrm{D}\end{array}$ & $\begin{array}{l}\mathrm{S} \\
\mathrm{M} \\
\mathrm{P}\end{array}$ & $\begin{array}{c}\text { SMA/ } \\
\text { SMK }\end{array}$ & $\begin{array}{l}\mathrm{D} \\
1\end{array}$ & $\begin{array}{l}\mathrm{D} \\
2\end{array}$ & $\begin{array}{l}\mathrm{D} \\
3\end{array}$ & $\begin{array}{l}S \\
1\end{array}$ & $\begin{array}{l}\mathrm{S} \\
2\end{array}$ & \\
\hline $\begin{array}{c}\text { Tombatu } \\
\text { Dua Induk }\end{array}$ & 1 & 4 & 10 & 0 & 1 & 0 & $\begin{array}{l}1 \\
2\end{array}$ & 0 & 28 \\
\hline $\begin{array}{l}\text { Tombatu } \\
\text { Dua Utara }\end{array}$ & 0 & 3 & 7 & $\mathrm{O}$ & $\mathrm{O}$ & 2 & 2 & 1 & 15 \\
\hline $\begin{array}{l}\text { Tombatu } \\
\text { Dua Barat }\end{array}$ & 0 & 4 & 16 & 0 & 0 & 0 & 5 & 1 & 26 \\
\hline $\begin{array}{c}\text { Tombatu } \\
\text { Dua Tengah }\end{array}$ & 2 & 5 & 6 & 0 & 0 & 1 & 8 & 0 & 22 \\
\hline Total & 3 & 16 & 39 & o & 1 & 3 & $\begin{array}{l}2 \\
7\end{array}$ & 2 & 91 \\
\hline
\end{tabular}

Dari Tabel 8 dapat dilihat bahwa desa Tombatu Dua Induk dengan jumlah 28 sampel memiliki tingkat pendidikan terakhir SD dengan jumlah 1 kepala keluarga dengan presentase 3,57\%, SMP berjumlah 4 kepala keluarga dengan presentase $14,28 \%$, SMA/SMK berjumlah 10 kepala keluarga dengan presentase $35,71 \%$, D2 berjumlah 1 kepala keluarga dengan presentase $3,57 \%, \mathrm{~S} 1$ berjumlah 12 kepala keluarga dengan presentase 42,85\%. Tingkat pendidikan terakhir desa Tombatu Dua Utara dengan jumlah 15 sampel menunjukan bahwa tingkat pendidikan terakhir SMP berjumlah 3 kepala keluarga dengan presentase $20 \%$, SMA/SMK berjumlah 7 kepala keluarga dengan presentase 46,66\%, D3 berjumlah 2 kepala keluarga dengan presentase 13,33\%, S1 berjumlah 2 kepala keluarga dengan presentase $13,33 \%$, dan $\mathrm{S} 2$ berjumlah 1 kepala keluarga dengan presentase $6,66 \%$. Tingkat pendidikan terakhir di desa Tombatu
Dua Barat dengan jumlah 26 sampel menunjukan bahwa untuk tingkat pendidikan terakhir SMP berjumlah 4 kepala keluarga dengan presentase $15,38 \%$, SMA/SMK berjumlah 16 kepala keluarga dengan presentase $61,53 \%, \mathrm{~S} 1$ berjumlah 5 kepala keluarga dengan presentase 19,23\%, dan S2 berjumlah 1 kepala keluarga dengan presentase $3,84 \%$. Tingkat pendidikan terakhir di desa Tombatu Dua Tengah dengan jumlah 22 sampel menunjukan bahwa untuk tingkat pendidikan terakhir SD berjumlah 2 kepala keluarga dengan presentase 9,09\%, SMP berjumlah 5 kepala keluarga dengan presentase 22,72\%, SMA/SMK berjumlah 6 kepala keluarga dengan presentase 27,27\%, D3 berjumlah 1 kepala keluarga dengan presentase $5,54 \%$, S1 berjumlah berjumlah 8 kepala keluarga dengan presentase $36,36 \%$. Tingkat pendidikan terakhir di wilayah Tombatu Dua Raya dengan jumlah 91 sampel menjukan bahwa tingkat pendidikan terakhir SD bejumlah 3 kepala keluarga dengan presentase 3,29\%, SMP berjumlah 16 kepala keluarga dengan presentase $17,58 \%$, SMA berjumlah 39 kepala keluarga dengan presentase 42,85\%, D2 berjumlah 1 kepala keluarga dengan presentase 1,09\%, D3 berjumlah 3 kepala keluarga dengan presentase 3,29\%, S1 berjumlah 27 kepala keluarga dengan presentase $29,67 \%$ dan S2 berjumlah 2 kepala keluarga dengan presentase 2,19\%.

\section{Pekerjaan $\left(\mathrm{X}_{2}\right)$}

Dari hasil kuisioner pekerjaan yang diberikan kepada 91 sampel kepala keluarga di wilayah Tombatu Dua Raya diperoleh data yang dapat dilihat pada Tabel 9.

Tabel 9. Deskripsi Pekerjaan Kepala Keluarga di Wilayah Tombatu Dua Raya

\begin{tabular}{|c|c|c|c|c|}
\hline \multirow{2}{*}{ Desa } & \multicolumn{3}{|c|}{ Pekerjaan } & \multirow{2}{*}{ Jumlah } \\
\cline { 2 - 4 } & Petani & Swasta & PNS & \\
\hline Tombatu Dua Induk & 12 & 4 & 12 & 28 \\
\hline Tombatu Dua Utara & 10 & 2 & 3 & 15 \\
\hline Tombatu Dua Barat & 16 & 4 & 6 & 26 \\
\hline Tombatu Dua Tengah & 11 & 3 & 8 & 22 \\
\hline Total & 49 & 13 & 29 & 91 \\
\hline
\end{tabular}

Nilai pada variabel seperti yang dapat dilihat di atas merupakan hasil kuisioner pekerjaan $\left(\mathrm{X}_{2}\right)$. Untuk pekerjaan di desa Tombatu Dua Induk dengan jumlah 28 sampel didapatkan untuk pekerjaan petani berjumlah 12 kepala keluarga dengan presentase 42,85\%, pekerjaan swasta berjumlah 4 kepala keluarga dengan presentase 14,29\%, dan pekerjaan PNS berjumlah 12 kepala keluarga dengan presentase 42,85\%, maka didapatkan untuk pekerjaan terbanyak di desa Tombatu Dua Induk adalah petani dan PNS dengan jumlah masing-masing 12 kepala keluarga dengan presentase $42,85 \%$ dan paling sedikit adalah swasta berjumlah 4 kepala keluarga dengan presentase 14,29\%. Perkerjaan kepala keluarga di desa Tombatu Dua Utara dengan jumlah 15 sampel didapatkan untuk pekerjaan sebagai petani berjumlah 10 kepala keluarga dengan presentase $66,66 \%$, pekerjaan swasta berjumlah 2 kepala keluarga dengan presentase $13,33 \%$, PNS berjumlah 3 kepala keluarga dengan presentase 20\%, maka didapatkan untuk pekerjaan terbanyak di desa Tombatu Dua Utara adalah petani dengan jumlah 10 kepala keluarga dengan presentase $66,66 \%$ dan paling 


\section{ANALISIS VARIABEL-VARIABEL YANG MEMPENGARUHI PENDAPATAN KELUARGA DI WILAYAH TOMBATU \\ DUA RAYA}

d’Cartesian Jurnal Matematika dan Aplikasi, Vol. 9, No. 1 (Maret, 2020): 62-71

sedikit adalah swasta berjumlah 2 kepala keluarga dengan presentase $13,33 \%$. Perkerjaan kepala keluarga di desa Tombatu Dua Barat dengan jumlah 26 sampel didapatkan untuk pekerjaan sebagai petani berjumlah 16 kepala keluarga dengan presentase 61,53\%, pekerjaan swasta berjumlah 4 kepala keluarga dengan presentase 15,38\%, PNS berjumlah 6 kepala keluarga dengan presentase $23,07 \%$, maka didapatkan pekerjaan kepala keluarga terbanyak di desa Tombatu Dua Barat adalah petani dengan jumlah 16 kepala keluarga dengan presentase $61,53 \%$ dan paling sedikit adalah swasta berjumlah 4 kepala keluarga dengan presentase $15,38 \%$. Pekerjaan kepala keluarga di desa Tombatu Dua Tengah dengan jumlah 26 sampel didapatkan untuk pekerjaan sebagai petani berjumlah 11 kepala keluarga dengan presentase $50 \%$, swasta berjumlah 3 kepala keluarga dengan presentase $13,64 \%$, PNS berjumlah 8 kepala keluarga dengan presentase $36,36 \%$, maka didapatkan pekerjaan kepala keluarga terbanyak di desa Tombatu Dua Tengah adalah petani dengan jumlah 11 orang dengan presentase 50\% dan paling sedikit adalah swasta berjumlah 3 kepala keluarga dengan presentase 13,64\%. Pekerjaan kepala keluarga di wilayah Tombatu Dua Raya dengan jumlah 91 sampel didapatkan hasil untuk pekerjaan sebagai petani berjumlah 49 kepala keluarga dengan presentase 53,84\%, Swasta berjumlah 13 kepala keluarga dengan presentase $14,29 \%$, PNS berjumlah 29 kepala keluarga dengan presentase $31,86 \%$.

\section{Luas Lahan Kering $\left(\mathrm{X}_{3}\right)$}

Dari hasil kuisioner Luas Rumah, yang diberikan kepada 91 sampel kepala keluarga di wilayah Tombatu Dua Raya, di peroleh data seperti yang dapat dilihat pada Tabel 10.

Tabel 10. Deskripsi Luas Lahan Kering di Wilayah Tombatu Dua Raya (Ha)

\begin{tabular}{|c|r|r|r|r|r|}
\hline Variabel & $\begin{array}{l}\text { Total } \\
\text { Sampel }\end{array}$ & $\begin{array}{l}\text { Rata- } \\
\text { rata }\end{array}$ & $\begin{array}{l}\text { St- } \\
\text { Dev }\end{array}$ & $\begin{array}{l}\text { Mini- } \\
\text { mum }\end{array}$ & $\begin{array}{l}\text { Maxi- } \\
\text { mum }\end{array}$ \\
\hline $\begin{array}{c}\text { Tombatu Dua } \\
\text { Induk }\end{array}$ & 28 & 1,357 & 1,07 & 0,000 & 5,000 \\
\hline $\begin{array}{c}\text { Tombatu Dua } \\
\text { Utara }\end{array}$ & 15 & 1,500 & 0,50 & 1,000 & 2,000 \\
\hline $\begin{array}{c}\text { Tombatu Dua } \\
\text { Barat }\end{array}$ & 26 & 1,192 & 0,89 & 0,000 & 3,000 \\
\hline $\begin{array}{c}\text { Tombatu Dua } \\
\text { Tengah }\end{array}$ & 22 & 1,523 & 1,25 & 0,000 & 5,000 \\
\hline Total & 91 & 1,374 & 0,99 & 0,000 & 5,000 \\
\hline
\end{tabular}

Nilai pada variabel seperti yang dapat dilihat pada tabel di atas merupakan hasil kuisioner Luas Lahan Kering $\left(X_{3}\right)$. Luas lahan kering kepala keluarga di desa Tombatu Dua Induk dengan jumlah 28 sampel memiliki rata-rata 1,357 Ha, standard deviasi 1,079 Ha, dengan luas lahan kering minimum o dan luas lahan maximum 5 Ha. Luas lahan kering kepala keluarga di desa Tombatu Dua Utara dengan jumlah 15 sampel memiliki rata-rata $1,5 \mathrm{Ha}$, standard deviasi $0,5 \mathrm{Ha}$, dengan luas lahan minimum $1 \mathrm{Ha}$ dan luas lahan maximum $2 \mathrm{Ha}$. Luas lahan kering kepala keluarga di desa Tombatu Dua Barat dengan jumlah 26 kepala keluarga memiliki rata-rata 1,192 Ha, standard deviasi o,895 Ha, dengan luas lahan minimum o dan luas lahan maximum $3 \mathrm{Ha}$. Luas lahan kering kepala keluarga di desa Tombatu Dua Tengah dengan jumlah 26 kepala keluarga memiliki rata-rata $1,523 \mathrm{Ha}$, standard deviasi 1,258 Ha, dengan luas lahan minimum o dan luas lahan maximum 5 Ha. Luas lahan kering di wilayah Tombatu Dua Raya dengan jumlah 91 sampel memiliki rata-rata 1,374 Ha, standard deviasi 0,999 Ha, dengan luas lahan minimum o dan luas lahan maximum $5 \mathrm{Ha}$.

\section{Luas Sawah $\left(\mathrm{X}_{4}\right)$}

Dari hasil kuisioner Luas Sawah, yang diberikan kepada 91 sampel kepala keluarga di wilayah Tombatu Dua Raya, di peroleh data seperti yang dapat dilihat pada Tabel 11.

Nilai pada variabel seperti yang dapat dilihat pada Tabel 11 merupakan hasil kuisioner Luas Sawah. Luas sawah kepala keluarga di desa Tombatu Dua Induk dengan jumlah 28 sampel memiliki rata-rata $0,2287 \mathrm{Ha}$, standard deviasi $0,4737 \mathrm{Ha}$, dengan luas sawah minimum o dan luas sawah maximum $2 \mathrm{Ha}$. Luas sawah kepala keluarga di desa Tombatu Dua Utara dengan jumlah 15 sampel memiliki rata-rata 0,1753 Ha, standard deviasi $0,3412 \mathrm{Ha}$, dengan luas sawah minimum o dan luas sawah maximum $1 \mathrm{Ha}$. Luas sawah kepala keluarga di desa Tombatu Dua Barat dengan jumlah 26 sampel memliki rata-rata 0,1064 Ha, standard deviasi 0,2716 Ha, dengan luas sawah minimum o dan luas sawah maximum $1 \mathrm{Ha}$.

Tabel 11. Deskripsi Luas Sawah di Wilayah Tombatu Dua Raya (Ha)

\begin{tabular}{|lr|r|r|r|r|r|}
\hline Variabel & & $\begin{array}{l}\text { Total } \\
\text { Sampel }\end{array}$ & $\begin{array}{l}\text { Rata- } \\
\text { rata }\end{array}$ & St-Dev & $\begin{array}{l}\text { Mini- } \\
\text { mum }\end{array}$ & $\begin{array}{l}\text { Maxi- } \\
\text { mum }\end{array}$ \\
\hline $\begin{array}{l}\text { Tombatu } \\
\text { Induk }\end{array}$ & Dua & 28 & 0,228 & 0,47 & 0,00 & $\begin{array}{r}2,000 \\
\text { o }\end{array}$ \\
\hline $\begin{array}{l}\text { Tombatu } \\
\text { Utara }\end{array}$ & Dua & 15 & 0,175 & 0,34 & 0,00 & 1,0000 \\
\hline $\begin{array}{l}\text { Tombatu } \\
\text { Barat Dua }\end{array}$ & 26 & 0,106 & 0,27 & 0,00 & 1,0000 \\
\hline $\begin{array}{l}\text { Tombatu } \\
\text { Tengah }\end{array}$ & Dua & 22 & 0,065 & 0,21 & 0,00 & 1,0000 \\
\hline \begin{tabular}{l} 
Total \\
\hline
\end{tabular} & 91 & 0,145 & 0,34 & 0,00 & $\begin{array}{r}2,000 \\
0\end{array}$ \\
\hline
\end{tabular}

Luas sawah kepala keluarga di desa Tombatu Dua Tengah dengan jumlah 22 sampel memiliki ratarata 0,0658 Ha, standard deviasi 0,2153 $\mathrm{Ha}$, dengan luas sawah minimum o dan luas sawah maximum $1 \mathrm{Ha}$. Maka total keseluruhan luas sawah kepala keluarga di Wilayah Tombatu Dua Raya dengan jumlah 91 sampel memiliki rata-rata $0,1456 \mathrm{Ha}$, standard deviasi 0,3479 Ha, dengan luas sawah minimum o dan luas sawah maximum $2 \mathrm{Ha}$.

\section{Luas Rumah $\left(\mathrm{X}_{5}\right)$}

Dari hasil kuisioner Luas Rumah, yang diberikan kepada 91 sampel kepala keluarga di wilayah Tombatu Dua Raya, di peroleh data seperti yang dapat dilihat pada Tabel 12.

Nilai pada variabel seperti yang dapat dilihat pada Tabel 12 merupakan hasil kuisioner luas rumah. Luas rumah desa Tombatu Dua Induk dengan jumlah 28 sampel memiliki rata-rata $96,02 \mathrm{M}^{2}$, standard deviasi 52,10 $\mathrm{M}^{2}$, dengan luas rumah minimum 30,00 $\mathrm{M}^{2}$ dan luas rumah maximum $292,50 \mathrm{M}^{2}$. Luas rumah desa Tombatu Dua Utara dengan jumlah 15 sampel memiliki rata-rata 94,5 $\mathrm{M}^{2}$, standard deviasi $43,7 \mathrm{M}^{2}$, dengan luas rumah minimum $35,0 \mathrm{M}^{2}$ dan luas rumah 
maximum 150,0 $\mathrm{M}^{2}$. Luas rumah desa Tombatu Dua Barat dengan jumlah 26 sampel memiliki rata-rata $72,85 \mathrm{M}^{2}$, standard deviasi 30,00 $\mathrm{M}^{2}$, dengan luas rumah minimum $36,00 \mathrm{M}^{2}$ dan luas rumah maximum $150,00 \mathrm{M}^{2}$.

Tabel 12. Deskripsi Luas Rumah di Wilayah Tombatu Dua Raya $\left(\mathrm{m}^{2}\right)$

\begin{tabular}{|l|l|l|l|l|l|}
\hline Dua Raya $\left(\mathrm{m}^{2}\right)$ & $\begin{array}{l}\text { Total } \\
\text { Sampel }\end{array}$ & $\begin{array}{l}\text { Rata- } \\
\text { rata }\end{array}$ & $\begin{array}{l}\text { St- } \\
\text { Dev }\end{array}$ & $\begin{array}{l}\text { Mini- } \\
\text { mum }\end{array}$ & $\begin{array}{l}\text { Maxi- } \\
\text { mum }\end{array}$ \\
\hline $\begin{array}{c}\text { Tombatu Dua } \\
\text { Induk }\end{array}$ & 28 & 96,02 & 52,1 & 30,00 & 292,5 \\
\hline $\begin{array}{c}\text { Tombatu Dua } \\
\text { Utara }\end{array}$ & 15 & 94,50 & 43,7 & 35,00 & 150,0 \\
\hline $\begin{array}{c}\text { Tombatu Dua } \\
\text { Barat }\end{array}$ & 26 & 72,85 & 30,0 & 36,00 & 150,0 \\
\hline $\begin{array}{c}\text { Tombatu Dua } \\
\text { Tengah }\end{array}$ & 22 & 84,3 & 54,9 & 18,0 & 300,0 \\
\hline Total & 91 & 86,31 & 46,4 & 18,00 & 300,0 \\
\hline
\end{tabular}

Luas rumah desa Tombatu Dua Tengah dengan jumlah 22 sampel memiliki rata-rata $84,3 \mathrm{M}^{2}$, standard deviasi $54,9 \mathrm{M}^{2}$, dengan luas rumah minimum $18,0 \mathrm{M}^{2}$ dan luas rumah maximum $300 \mathrm{M}^{2}$. Maka untuk luas rumah di wilayah Tombatu Dua Raya dengan jumlah 91 sampel memiliki rata- rata $86,31 \mathrm{M}^{2}$, standard deviasi 46,45 $\mathrm{M}^{2}$, dengan luas rumah minimum $18,00 \mathrm{M}^{2}$ dan luas rumah maximum $300 \mathrm{M}^{2}$.

\section{Jenis Rumah $\left(\mathrm{X}_{6}\right)$}

Dari hasil kuisioner jenis rumah yang diberikan kepada 91 sampel kepala keluarga diwilayah Tombatu Dua Raya, di peroleh data seperti yang dapat dilihat pada Tabel 13 .

Tabel 13. Deskripsi Jenis Rumah di Wilayah Tombatu Dua Raya

\begin{tabular}{|c|l|l|l|l|}
\hline \multirow{2}{*}{ Desa } & \multicolumn{3}{|c|}{ Jenis Rumah } & $\begin{array}{l}\text { Jum- } \\
\text { lah }\end{array}$ \\
\cline { 2 - 4 } & Papan & $\begin{array}{l}\text { Semi } \\
\text { Permanen }\end{array}$ & $\begin{array}{l}\text { Perma- } \\
\text { nen }\end{array}$ & 19 \\
\hline $\begin{array}{c}\text { Tombatu Dua } \\
\text { Induk }\end{array}$ & 1 & 8 & 28 \\
\hline Tombatu Dua Utara & 2 & 4 & 9 & 15 \\
\hline Tombatu Dua Barat & 4 & 2 & 20 & 26 \\
\hline $\begin{array}{c}\text { Tombatu Dua } \\
\text { Tengah }\end{array}$ & 1 & 1 & 20 & 22 \\
\hline Total & 8 & 15 & 68 & 91 \\
\hline
\end{tabular}

Nilai seperti yang dapat dilihat pada tabel diatas merupakan hasil kuisioner variabel jenis rumah yaitu untuk desa Tombatu Dua Induk dengan jumlah 28 sampel didapatkan hasil 1 kepala keluarga untuk jenis rumah papan dengan persentase sebesar $3.6 \%$, untuk jenis rumah semi permanen didapatkan 8 kepala keluarga dengan persentase $28.5 \%$, dan jenis rumah permanen sebanyak 19 kepala keluarga dengan persentase sebesar 68\% maka didapatkan untuk Desa Tombatu Dua Induk terbanyak adalah jenis rumah permanen dengan jumlah total 19 kepala keluarga (68\%) dan paling sedikit adalah jenis rumah papan dengan jumlah 1 kepala keluarga (3.5\%), Desa Tombatu Dua Utara dengan jumlah 15 sampel didapatkan hasil 2 kepala keluarga memiliki jenis rumah papan dengan persentase $13 \%$, untuk jenis rumah semi permanen didapatkan 4 kepala keluarga dengan persentase $26.7 \%$, dan jenis rumah permanen didapatkan 9 kepala keluarga dengan persentase sebesar 60\%. Maka didapatkan untuk Desa Tombatu Dua Utara terbanyak adalah jenis rumah permanen dengan total 9 kepala keluarga (60\%) dan paling sedikit adalah jenis rumah papan dengan total 2 kepala keluarga (13.3\%), Desa Tombatu Dua Barat dengan jumlah 26 sampel didapatkan 4 kepala keluarga untuk jenis rumah papan dengan persentase sebesar $15.4 \%$, untuk jenis rumah semi permanen didapatkan 2 kepala keluarga dengan persentase $7.7 \%$, untuk jenis rumah permanen didapatkan total 20 kepala keluarga dengan persentase sebesar 77\%, maka didapatkan untuk jenis rumah Desa Tombatu Dua barat terbanyak adalah jenis rumah permanen (77\%) dan paling sedikit adalah jenis rumah semi permanen dengan total 2 kepala keluarga (7.7\%), Desa Tombatu Dua Tengah dengan jumlah 22 sampel didapatkan 1 kepala keluarga untuk jenis rumah papan dengan persentase sebesar $4.5 \%$, untuk jenis rumah semi permanen didapatkan total 1 kepala keluarga dengan persentase sebesar $4.5 \%$, dan jenis rumah permanen sebanyak 20 kepala keluarga dengan persentase sebesar 90\%. Jenis rumah di Wilayah Tombatu Dua Raya dengan jumlah 91 sampel terbanyak adalah jenis rumah permanen sebanyak 68 kepala keluarga dengan presentase $74,72 \%$, semi permanen sebanyak 15 kepala keluarga dengan presentase $16,48 \%$, papan sebanyak 8 kepala keluarga dengan presentase 8,79\%.

\section{Daya Listrik $\left(\mathrm{X}_{7}\right)$}

Dari hasil kuisioner daya listrik yang diberikan kepada 91 sampel kepala keluarga di wilayah Tombatu Dua Raya, diperoleh data seperti yang dapat dilihat pada Tabel 14.

Tabel 14. Deskripsi Daya Listrik di Wilayah Tombatu Dua Raya

\begin{tabular}{|c|c|c|c|c|c|}
\hline \multirow{2}{*}{ Desa } & \multicolumn{4}{|c|}{ Daya Listrik } & \multirow{2}{*}{ Jumlah } \\
\cline { 2 - 5 } & 450 & 900 & 1300 & 2200 & \\
\hline Tombatu Dua Induk & 20 & 8 & 0 & 0 & 28 \\
\hline Tombatu Dua Utara & 15 & 0 & 0 & 0 & 15 \\
\hline Tombatu Dua Barat & 23 & 3 & 0 & 0 & 26 \\
\hline Tombatu Dua Tengah & 17 & 3 & 1 & 1 & 22 \\
\hline Total & 75 & 14 & 1 & 1 & 91 \\
\hline
\end{tabular}

Nilai seperti yang dapat dilihat pada Tabel 14 merupakan hasil kuisioner variabel daya listrik yaitu desa Tombatu Dua Induk didapatkan hasil 20 dengan persentase sebesar $71,42 \%$ memiliki daya listrik sebesar 450 Watt, daya listrik sebesar 900 Watt didapatkan total 8 kepala keluarga dengan persentase $28,57 \%$, daya listrik sebesar 1300 Watt dan 2200 Watt adalah o, dengan total kepala keluarga sebesar 28. Desa Tombatu Dua Utara didapatkan hasil 15 daya listrik 450 Watt dengan persentase $100 \%$ dengan total kepala keluarga sebanyak 15. Desa Tombatu Dua Barat didapatkan hasil 23 dengan persentase 88,5\% memiliki daya listrik sebesar 450 Watt, daya listrik sebesar 900 Watt didapatkan total 3 kepala keluarga dengan persentase sebesar 11,5\%, dan didapatkan hasil o untuk masingmasing daya listrik 1300 Watt, 2200 Watt. Desa Tombatu Dua Tengah didapatkan hasil 17 dengan persentase sebesar 77,3\% daya listrik sebesar 450 Watt, daya listrik sebesar 900 Watt didapatkan total 3 kepala keluarga dengan presentase $13,63 \%$, dan masingmasing 1 kepala keluarga memiliki daya listrik sebesar 


\section{ANALISIS VARIABEL-VARIABEL YANG MEMPENGARUHI PENDAPATAN KELUARGA DI WILAYAH TOMBATU \\ DUA RAYA}

d'Cartesian Jurnal Matematika dan Aplikasi, Vol. 9, No. 1 (Maret, 2020): 62-71

1300 Watt dan 2200 Watt dengan persentase yang sama sebesar 4,5\%. Daya listrik di Wilayah Tombatu Dua Raya didapatkan hasil sebanyak 75 kepala keluarga memiliki daya listrik sebesar 450 Watt dengan presentase $82,41 \%$, daya listrik sebesar 900 Watt didapatkan total 14 kepala keluarga dengan presentase $15,38 \%$, dan masing-masing 1 kepala keluarga memiliki daya listrik sebesar 1300 Watt dan 2200 Watt dengan persentase yang sama sebesar $1,09 \%$.

\section{Analisis Data}

\section{Uji Asumsi Klasik}

Dari 91 sampel yang diperoleh dari hasil kuisioner penelitian, didapatkan ada dua pengamatan yang pendapatan keluarganya mempengaruhi pendapatan keluarga yang lain, pengamatan pertama memiliki pendapatan keluarga sebesar Rp.10.000.000 dengan tingkat pendidikan S1, pekerjaan sebagai pengusaha (LPG, cengkih, vanili dan kelapa), memiliki luas lahan kering sebesar $5 \mathrm{Ha}$, luas sawah sebesar 2 $\mathrm{Ha}$, luas rumah sebesar $120 \mathrm{M}^{2}$ dengan jenis rumah permanen dan daya listrik 900 Watt. Pengamatan kedua memiliki pendapatan sebesar Rp.10.000.000 dengan tingkat pendidikan S2, pekerjaan sebagai PNS (Camat), memiliki luas lahan kering sebesar $3 \mathrm{Ha}$, luas sawah sebesar $1 \mathrm{Ha}$, luas rumah $120 \mathrm{M}^{2}$ dengan jenis rumah permanen dan daya listrik 900 Watt.

Gambar 1 menunjukan uji asumsi klasik untuk variabel bebas dan semua variabel tidak bebas.

\section{Normalitas}

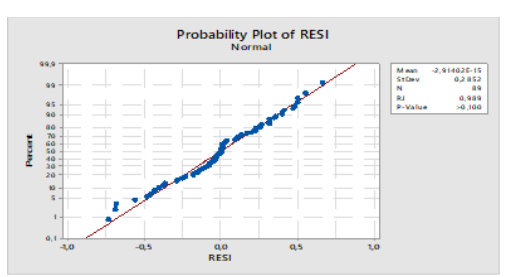

Gambar 1. Plot Normalitas

Untuk hasil uji Ryan-Joiner (Shimilar to Shapiro-Wilk) kita dapat mengambil keputusan berdasarkan uji hipotesis sebagai berikut :

$\mathrm{H}_{0}$ : Distribusi data memenuhi asumsi normalitas

$\mathrm{H}_{1}$ : Distribusi data tidak memenuhi asumsi normalitas Jika nilai $\mathrm{p}<0.05$ maka tolak $\mathrm{H}_{0}$, atau di interpretasikan sebagai tidak normal.

Berdasarkan nilai $\mathrm{p}>0,100$, maka terima $\mathrm{H}_{0}$, artinya data tersebut normal.

\section{a. Uji Heteroskedastisitas}

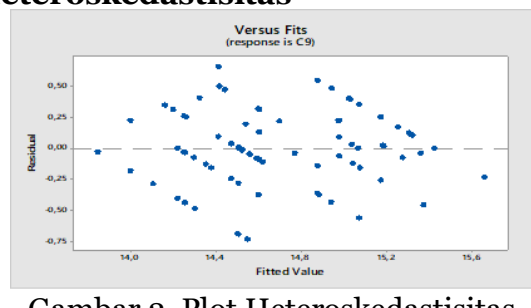

Uji heteroskedastisitas dapat dilihat dari plot yang ada pada Gambar 2, apabila titik berada di atas dan dibawah sumbu nol secara acak dan tanpa pola tertentu maka dikatakan tidak ada indikasi Heteroskedastisitas (homogen).

\subsubsection{Analisis Regresi}

Berdasarkan data yang didapat dan diolah dengan menggunakan aplikasi Minitab 18 di peroleh hasil sebagaimana pada Tabel 15 .

Tabel 15. Output Regresi Linier Berganda

Analysis of Variance

\begin{tabular}{|l|r|r|r|r|r|}
\hline Source & DF & Adj SS & Adj MS & F-Value & P-Value \\
\hline Regression & 16 & 14,213 & 0,888 & 8,94 & 0,000 \\
\hline X3 & 1 & 0,352 & 0,351 & 3,54 & 0,064 \\
\hline X4 & 1 & 0,009 & 0,009 & 0,10 & 0,757 \\
\hline$X_{5}$ & 1 & 0,000 & 0,000 & 0,00 & 0,946 \\
\hline X1 & 6 & 1,1922 & 0,198 & 2,00 & 0,077 \\
\hline X2 & 2 & 1,075 & 0,537 & 5,41 & 0,006 \\
\hline $\mathrm{X} 6$ & 2 & 0,348 & 0,174 & 1,76 & 0,180 \\
\hline X7 & 3 & 0,871 & 0,290 & 2,92 & 0,040 \\
\hline Error & 72 & 7,157 & 0,099 & & \\
\hline Lack-of-Fit & 66 & 7,135 & 0,108 & 29,27 & 0,000 \\
\hline Pure Error & 6 & 0,022 & 0,003 & & \\
\hline Total & 88 & 21,370 & & & \\
\hline
\end{tabular}

Model Summary

\begin{tabular}{|r|r|r|r|}
\hline $\mathrm{S}$ & $\mathrm{R}-\mathrm{sq}$ & $\mathrm{R}$-sq(adj) & R-sq(pred) \\
\hline 0,315289 & $66,51 \%$ & $59,07 \%$ & $*$ \\
\hline
\end{tabular}

Coefficients

\begin{tabular}{|c|c|c|c|c|c|}
\hline Term & Coef & SE Coef & T-Value & P-Value & VIF \\
\hline Constant & 13,840 & 0,204 & 67,90 & 0,000 & \\
\hline $\mathrm{X}_{3}$ & 0,0940 & 0,0499 & 1,88 & 0,064 & 1,85 \\
\hline $\mathrm{X}_{4}$ & $-0,051$ & 0,163 & $-0,31$ & 0,757 & 1,78 \\
\hline $\mathrm{X}_{5}$ & 0,00008 & 0,00114 & 0,07 & 0,946 & 2,51 \\
\hline \multicolumn{6}{|l|}{$\mathrm{X} 1$} \\
\hline 2 & 0,059 & 0,206 & 0,29 & 0,776 & 5,60 \\
\hline 3 & 0,309 & 0,199 & 1,55 & 0,125 & 8,71 \\
\hline 5 & $-0,284$ & 0,452 & $-0,63$ & 0,532 & 2,03 \\
\hline 6 & $-0,013$ & 0,296 & $-0,04$ & 0,965 & 2,56 \\
\hline 7 & 0,056 & 0,301 & 0,18 & 0,854 & 16,83 \\
\hline 8 & 0,489 & 0,475 & 1,03 & 0,306 & 2,24 \\
\hline \multicolumn{6}{|l|}{$\mathrm{X} 2$} \\
\hline 2 & 0,370 & 0,138 & 2,68 & 0,009 & 1,99 \\
\hline 3 & 0,725 & 0,253 & 2,87 & 0,005 & 12,31 \\
\hline \multicolumn{6}{|l|}{ X6 } \\
\hline 2 & 0,222 & 0,161 & 1,38 & 0,172 & 3,25 \\
\hline
\end{tabular}




\begin{tabular}{|c|r|r|r|r|r|}
\hline Term & Coef & SE Coef & T-Value & P-Value & VIF \\
\hline 3 & 0,256 & 0,137 & 1,87 & 0,065 & 3,21 \\
\hline $\mathrm{X}_{7}$ & & & & & \\
\hline 2 & 0,297 & 0,134 & 2,21 & 0,030 & 1,75 \\
\hline 3 & 0,461 & 0,481 & 0,96 & 0,342 & 2,31 \\
\hline 4 & 0,586 & 0,355 & 1,65 & 0,103 & 1,25 \\
\hline
\end{tabular}

Berdasarkan output regresi berganda, maka dapat disimpulkan berdasarkan hipotesis sebagai berikut:

$\mathrm{H}_{\mathrm{o}}: \beta_{1}=\beta_{2}=\beta_{3}=\beta_{4}=\beta_{5}=\beta_{6}=\beta_{7}=\mathrm{o}$

$\mathrm{H}_{1}$ : minimal ada satu $\beta$ tidak sama dengan nol

Untuk $\alpha=5 \%=0,05$

Karena nilai $\mathrm{P}=0.000$ atau $<0,05$ maka tolak $\mathrm{H}_{\mathrm{o}}$. Artinya bahwa minimal ada 1 variabel $\mathrm{X}$ memberi pengaruh signifikan terhadap pendapatan keluarga di wilayah Tombatu Dua Raya(Y). Nilai $\mathrm{R}^{2}=66,51 \%$, artinya sebesar $66.51 \%$ keadaan dari pendapatan keluarga di wilayah Tombatu Dua Raya dapat dijelaskan oleh model regresi di atas.

\section{Pengujian Hipotesis Koefisien Regresi Berganda}

Berdasarkan output dari pengujian hipotesis koefisien regresi berganda pada Tabel 14, Maka dapat disimpulkan berdasarkan hipotesis sebagai berikut:

a) Luas lahan kering $\left(\mathrm{X}_{3}\right)$

$\mathrm{H}_{\mathrm{o}}: \beta_{3}=\mathrm{o}$

$\mathrm{H}_{1}: \beta_{3} \neq \mathrm{O}$

Untuk $\alpha=0.05$

Karena nilai $\mathrm{P}=0,064>0,05$ maka terima $\mathrm{H}_{0}$. Artinya bahwa luas lahan $\left(\mathrm{X}_{3}\right)$ tidak memberi pengaruh yang signifikan terhadap pendapatan keluarga di wilayah Tombatu Dua Raya(Y).

Untuk $\alpha=0.1$

Karena nilai $\mathrm{P}=0,064<0,1$ maka tolak $\mathrm{H}_{0}$. Artinya bahwa luas lahan $\left(\mathrm{X}_{3}\right)$ memberi pengaruh yang signifikan terhadap pendapatan keluarga di wilayah Tombatu Dua Raya(Y).

b) Luas sawah $\left(\mathrm{X}_{4}\right)$

$\mathrm{H}_{\mathrm{o}}: \beta_{4}=\mathrm{O}$

$\mathrm{H}_{1}: \beta_{4} \neq 0$

Untuk $\alpha=0.05$

Karena nilai $\mathrm{P}=0,757>0,05$ maka terima $\mathrm{H}_{0}$. Artinya bahwa luas sawah $\left(\mathrm{X}_{4}\right)$ tidak memberi pengaruh yang signifikan terhadap pendapatan keluarga di wilayah Tombatu Dua Raya(Y).

c) Luas rumah $\left(\mathrm{X}_{5}\right)$

$\mathrm{H}_{\mathrm{o}}: \beta_{5}=\mathrm{O}$

$\mathrm{H}_{1}: \beta_{5} \neq \mathrm{O}$

Untuk $\alpha=0.05$

Karena nilai $\mathrm{P}=0,946>0,05$ maka terima $\mathrm{H}_{0}$. Artinya bahwa luas rumah $\left(\mathrm{X}_{5}\right)$ tidak memberi pengaruh yang signifikan terhadap pendapatan keluarga di wilayah Tombatu Dua Raya(Y).

d) Pendidikan $\left(\mathrm{X}_{1}\right)$

$\mathrm{H}_{\mathrm{o}}: \beta_{1}=\mathrm{o}$

$\mathrm{H}_{1}: \beta_{1} \neq 0$

Untuk $\alpha=0.05$

Karena nilai $\mathrm{P}=0,077>0,05$ maka terima $\mathrm{H}_{0}$. Artinya bahwa pendidikan $\left(\mathrm{X}_{1}\right)$ tidak memberi pengaruh yang signifikan terhadap pendapatan keluarga di wilayah Tombatu Dua Raya(Y).

e) Pekerjaan $\left(\mathrm{X}_{2}\right)$

$\mathrm{H}_{\mathrm{o}}: \beta_{2 \text { petani }}=\beta_{2 \text { swasta }}$

$\mathrm{H}_{1}: \beta_{2 \text { petani }} \neq \beta_{\text {2swasta }}$

Untuk $\alpha=0.05$

Karena nilai $\mathrm{P}=0,009<0,05$

maka tolak $\mathrm{H}_{\mathrm{o}}$. Artinya bahwa kepala keluarga yang mempunyai pekerjaan swasta memiliki pendapatan berbeda dengan kepala keluarga yang memiliki pekerjaan petani.

$\mathrm{H}_{\mathrm{o}}: \beta_{2 \text { petani }}=\beta_{2 \mathrm{PNS}}$

$\mathrm{H}_{1}: \beta_{2 \text { petani }} \neq \beta_{2 \mathrm{PNS}}$

Untuk $\alpha=0.05$

Karena nilai $\mathrm{P}=0,005<0,05$ maka tolak $\mathrm{H}_{0}$. Artinya bahwa kepala keluarga yang mempunyai pekerjaan PNS memiliki pendapatan berbeda dengan kepala keluarga yang memiliki pekerjaan petani.

f) Luas Rumah $\left(\mathrm{X}_{6}\right)$

$\mathrm{H}_{\mathrm{o}}: \beta_{6}=\mathrm{O}$

$\mathrm{H}_{1}: \beta_{6} \neq \mathrm{O}$

Untuk $\alpha=0.05$

Karena nilai $\mathrm{P}=0,180>0,05$ maka terima $\mathrm{H}_{0}$. Artinya bahwa Luas Rumah $\left(\mathrm{X}_{6}\right)$ tidak memberi pengaruh yang signifikan terhadap pendapatan keluarga di wilayah Tombatu Dua Raya(Y).

g) Daya Listrik $\left(\mathrm{X}_{7}\right)$

$\mathrm{H}_{0}: \beta_{900}=\beta_{450}$

$\mathrm{H}_{1}: \beta_{900} \neq \beta_{450}$

Untuk $\alpha=0.05$

Karena nilai $\mathrm{P}=0,030<0,05$ maka tolak $\mathrm{H}_{0}$. Artinya bahwa keluarga yang memiliki Daya Listrik 900 Watt memiliki pendapatan berbeda dengan keluarga yang memiliki daya listrik 450 Watt.

Berdasarkan pengujian hipotesis regresi berganda pada tabel 14, maka model regresi yang terbentuk adalah sebagai berikut :

$$
\begin{aligned}
\hat{Y}= & 13,840+0,0940 \mathrm{X}_{3}-0,051 \mathrm{X} 4+0,00008 \mathrm{X}_{5} \\
& +0,0 \mathrm{X} 1 \_1+0,059 \mathrm{X} 1 \_2+0,309 \mathrm{X} 1 \_3- \\
& 0,284 \mathrm{X} 1 \_5-0,013 \mathrm{X} 1 \_6+0,056 \mathrm{X} 1 \_7 \\
& +0,489 \mathrm{X} 1 \_8+0,0 \mathrm{X} 2 \_1+0,370 \mathrm{X} 2 \_2 \\
& +0,725 \mathrm{X} 2 \_3+0,0 \mathrm{X} 6 \_1+0,222 \mathrm{X} 6 \_2 \\
& +0,256 \mathrm{X} 6 \_3+0,0 \mathrm{X} 7 \_1+0,297 \mathrm{X} 7 \_2 \\
& +0,461 \mathrm{X} 7 \_3+0,586 \mathrm{X}_{7} \_4
\end{aligned}
$$

\section{KESIMPULAN DAN SARAN}

\section{Kesimpulan}

1. Pendapatan keluarga diwilayah Tombatu Dua Raya dengan Total sampel 91 sampel, di peroleh ratarata Rp.2.835.165, standard deviasi Rp.1.673.411, dengan pendapatan minimum berjumlah Rp.1.00o.0oo dan pendapatan maximum berjumlah Rp.10.000.000.

2. Luas lahan kering mempengaruhi pendapatan keluarga di wilayah Tombatu Dua Raya

3. Kepala keluarga yang mempunyai pekerjaan swasta dan PNS memiliki pendapatan berbeda dengan kepala keluarga yang memiliki pekerjaan petani. Demikian juga keluarga yang memiliki Daya Listrik 900 Watt memiliki pendapatan berbeda dengan keluarga yang memiliki daya listrik 450 Watt. 


\section{ANALISIS VARIABEL-VARIABEL YANG MEMPENGARUHI PENDAPATAN KELUARGA DI WILAYAH TOMBATU \\ DUA RAYA}

d’Cartesian Jurnal Matematika dan Aplikasi, Vol. 9, No. 1 (Maret, 2020): 62-71

\section{Saran}

Penelitian selanjutnya dapat menggunakan metode regresi lainnya untuk menganalisis variabelvariabel yang mempengaruhi pendapatan keluarga agar dapat dilakukan perbandingan metode

\section{REFERENSI}

1. Kadariyah. 1982. Analisa Pendapatan Nasional. Jakarta: Bima Aksara.

2. Guritno, 1992. Kamus Ekonomi, Bisnis, Pembukuan. Yogyakarta : Andi Offset.

3. Sutyastie dan Prijono, 2002. Kemiskinan dan Ketidakmerataan di Indonesia. Jakarta: PT Rineka Cipta.

4. Lawendatu, J., J. Kekenusa., dan D. Hatidja. 2014. Regresi Linier Berganda Untuk Menganalisa Pendapatan Petani Pala. Jurnal de Cartesian 1(3): 66-72

5. Wohon, C.S., D. Hatidja., dan N. Nainggolan. 2017. Penentuan Model Regresi Terbaik Dengan Menggunakan Metode Stepwise. Jurnal Ilmiah Sains 17(2): 82-83.

6. Kutner, M.H., C.J. Nachtsheim., dan J. Neter. 2004. Applied Linear Regression Models. 4th ed. New York: McGraw-Hill Companies, Inc.

7. Draper, N. dan Smith, H. 1992. Analisis Regresi Terapan. Edisi Kedua. Terjemahan Oleh Bambang Sumantri. Jakarta: Gramedia Pustaka Utama.

8. Gujarati, N.D. 2003.Basic Econometrics. 4th ed. New York: McGraw-Hill Companies, Inc.

9. Myers, R.H. 1990. Classical and Modern Regression with Application, 2nd Ed. Boston: PWS-KENT Publishing Company.

10. Hatidja, D. 2006. Analisis Regresi. Bahan Ajar. Manado : Materi Mata Kuliah Untuk Mahasiswa Semester IV Jurusan Matematika FMIPA UNSRAT.

11. Ghozali, I. 2011. Aplikasi Analisis Multivariate Dengan Program IBM SPSS 19 (edisi kelima.) Semarang: Universitas Diponegoro.

12. Akdon dan Riduwan , 2005. Rumus dan Data Dalam Aplikasi Statistika. Bandung: Alfabeta.

Ridel Runturambi (ridelrunturambio7@gmail.com)

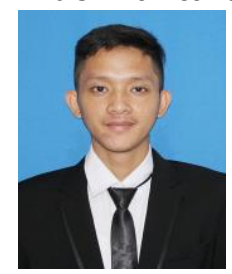
lahir pada 26 Mei 1998 di Tombatu. Melanjutkan Kuliah di Jurusan Matematika Fakultas Matematika dan Ilmu Pengetahuan Alam Universitas Sam Ratulangi. Tahun 2019 adalah tahun terakhir Pendidikan penulis. Jurnal ini adalah hasil dari penelitian yang di publikasikan.

Nelson Nainggolan (n-nelson@unsrat.ac.id)

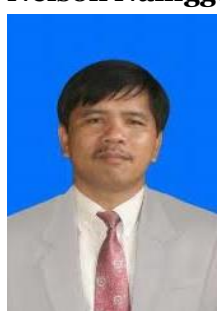

Lahir di Tapanuli Utara tanggal 9 Maret 1967. Gelar sarjana pendidikan Matematika diperoleh tahun 1992 di FMIPA IKIP Negeri Medan. Tahun 1996 menyelesaikan studi S2, di jurusan Matematika ITB Bandung. Tahun 2011 menyelesaikan studi S3 pada bidang Matematika di Universitas Padjadjaran Bandung. Saat ini menjadi pengajar akademik tetap di jurusan Matematika Fakultas Matematika dan Ilmu Pengetahuan Alam Universitas Sam Ratulangi Manado.

Djoni Hatidja (dhatidja@unsrat.ac.id) Lahir di

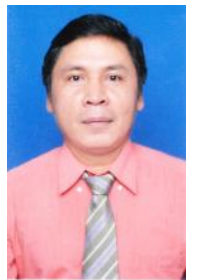
Minahasa Tenggara tanggal 16 Juli 1969. Gelar Sarjana diperoleh tahun 1994 di Program Studi Statistika IPB, Bogor. Tahun 2000 menyelesaikan studi s2 di Program Studi Statistika Program Pasca Sarjana IPB, Bogor. Saat ini menjadi pengajar di Jurusan Matematika Fakultas Matematika dan Sam Ratulangi Manado.
Ilmu Pengetahuan Alam Universitas

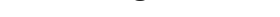

